\title{
Peace, Peace to the Far and the Near: Who Comes First?
}

\author{
Jean-Francois REY \\ Lille University
}

\begin{abstract}
Peace's gift when you meet the other is not a polite phrase. This is courtesy or politeness which institutes a priority order: first the far, then the near. In Levinas' thought, there is a peace of pure rest, "at home” and a peace which questions my own identity. A fair peace is a peace where the foreigner goes before me. "Close peace is my responsibility for the other man,” says Levinas. It is an "ethical” peace, different from political peace. Peace comes from my own responsibility for the other, until it could die for him. Maybe this welcome will seem crazy, but it is moderated, i.e., involved and estimated in politics. Levinas knows the political moment. But he puts it to its place: to welcome the strangers is an objective fact. Proximity of social link and perspective of far cannot be separated. It's a matter of politics and right.
\end{abstract}

Keywords: peace, proximity, against Hobbes, the other, the stranger, history

In December 1941, in the jail where he is waiting before his trial by the government of Vichy, Leon Blum writes for his defense a little book whose title is: On a Human Scale. ${ }^{1}$ In conclusion, we can read what Emmanuel Levinas noticed and he emphasizes: "We are working IN the present, not FOR the present.” This is a foreword to political people whose horizon is limited to their own reelection. Kant said the same thing about education: You must not bring up children to adapt to the present world, but for the world to come. This is true too, when speaking about space in these Nietzsche's words: "May future and the most remote things the rule of all your present days. I don't teach you love for the near, I advise you for the love of far.” These words, Léon Blum's ones, as well as Nietzsche's, are a distant echo to the biblical book of Isaiah: "Peace, peace the far and the near!” This sentence will be repeated by Maurice Blanchot in a very important preface he wrote for an exhibition's catalogue devoted to the Bible. ${ }^{2}$ It is true that Isaiah's book calls upon to mind at many moments peace. Not only for Israel's safety, which is an important thing, but to give it to the nations. Isaiah's book, as well as other biblical books, is not irenic. Violence and grief are there, but when you rest on Jerusalem, you can give peace to the world. The order of apparition is not indifferent: It is not an expansion, from near to near, from proximity to proximity, but from the far. German language, especially in Heidegger's use, does not take distance as a taking away, but as the suppression of the far. Entfernen, in German, means reducing the distance. For Heidegger the Dasein's behavior with space is "vanishing the far," coming near in such a way that "there is in the Dasein an inclination to proximity.” But here, to start out of far, it is open space and time to a concept of proximity which is not assimilation of otherness of the other man, but an address, a gift. What do we give the far at first? We give peace. But is it not better to give it to the near? Why such a priority? Who gives first? In what extend the gift of peace is meaning approach and manner towards the near? How does proximity and

Jean-Francois REY, Dr., professor, Department of Philosophy, Lille University, France; main research fields: Ethics, Political Philosophy, Education and Psychopathology. 
peace join one another? What conclusion could we draw about aims of politics? Every question needs an explanation about proximity. This explanation comes before the question of peace in meta-political way.

Relation to the neighbor is an approach. "Far" and "near," as substantives, must find again the verbal forms they condense and fix in formulas. In his essay, "Language and Proximity,” Levinas writes: "Approach, being a neighbor, is not the same as knowledge or conscience which we could have of it." Knowledge and conscience are substantives. But before substantive there is a verb: The reduction of verb into a substance reveals something of contact before conscience. We ought to return to "contact" its concrete value. "Contact" is like the neologism "pathic" (from ancient Greek: Pathei Mathos); it denotes sensations: sweet or rough, light or heavy. Contact is at first a question of touch. What is given to us as life and bones in contact, is the concreteness of things, their proximity. Being close to things is, in a phenomenological way, an "existential" ("proximity of things is poetry," says Levinas). Like the French poet, Francis Ponge, the philosopher praises proximity. But with Levinas, we discover another existential: being with and for the other. Proximity comes before manifestation. Contact introduces us into the sphere of human. Contact is contact with skin. But it is also language, without mediation. Levinas celebrates the touch which extends beyond the view as perception: "The sight caresses the eye. We see and hear as well as well as we touch.” The proximity of the neighbor enlightens the proximity of things: familiar spaces or things, images, inflexions of voices. Contact is familiarity and tenderness. It overflows the "noetico-noematic" structure: "Proximity, beyond intentionality, is relation with ${ }^{3}$ the neighbor in a moral sense." Here lies the specificity of contact in regard of our relations with things. Things are what they are for me, from the radiant center of the other. Things are the surroundings of the other man. Still they are always things. On the contrary, the contact with the other needs the language. "Language as contact touches my neighbor with its unideal unity." ${ }^{4}$ Things can be reproduced in series, but the neighbor is not multiple. He means for himself and for me from his approach without mediation. "It's from approach that the very notion of face is essential." Approach is not a familiar capture, an appropriation. As well as face overflows its expressive manifestations, proximity is less a familiarity than an obsession. It is not a spatial localization you could limit. It is excess. Proximity with my neighbor is always out of time. Psychological and moral consciousness is always late to the date of the neighbor. The neighbor is not synchronous with consciousness, nor in a harmonious rhythm with it.

In Otherwise than Being or beyond the Essence, Levinas always defines proximity as approach neighborhood and contact (Chapter 3: Sensibility and Proximity). These three delimitations are enough to move apart the geometrical meaning of space expressed in the word "contiguity." There are two ways in sizing oneself with space: surveying or dwelling. When Levinas introduces the spatial meaning of contiguity, he wants to show us that contiguity can be understood in its human signification. Therefore, the spatial meaning is subverted: Dwelling comes before every kind of measure. The presence of a human being in space overflows the impassivity of space, the absolute coexistence of every point with the others, and, final point of this enumeration, the Being. Levinas disputes the inner privilege of spatial contiguity which would rest in an everlasting state of untroubled state. On the contrary approach, reducing the distance, introduces unquietness in contiguity. To the delimited and assigned place, it brings non-place. Approach is the movement by which the neighbor, ever speaking, becomes his own superlative (in roman language: proximus).

This phenomenology of approach is bound in Otherwise than Being to justice, in one hand, and brotherhood in the other hand. It is linked with justice by the Third: justice delimits a space for appearance, reintroducing measure, without freezing in a structure. It also tends towards brotherhood as non-indifference. If 
approach, in a full conscience of itself, makes a theme of what she is approaching, i.e., the neighbor, it is like a caress who, without love, would be like a pure palpation, indifferent to the other. The neighbor approaches as a brother and my conscience of his approach belongs to brotherhood. But brotherhood is not a new kind, human kind, where we should be like children of the same mother. On the contrary, this brotherhood comes before every filiation, every consciousness, every representation. It is the very meaning of proximity. Levinas writes: "Mankind, to which proximity refers, must not be understood as consciousness-i.e., as identity of a self, endowed with knowledge, or-it is the same thing of powers." individuals. It means that the neighbor cannot be estimated: Is he enough the same, is he worth of company, inter course, conversation? Proximity misses what society is made of. The social intrigue, such as the three unities rule in French classical theater, is at first a multiplicity synthesis as other ones. Non indifference and obsession with the superlative approach will ever fail to him. So proximity is not only a relation between two contemporary, synchronous terms: together in the same place. This is a rational, therefore peaceful, coexistence. But it claims for asking for this peace, from obsessive non indifference of the Other over the Same, rather as an external intrusion. We must ask for peace as coexistence-in this meaning political, diplomatic — and peace as a gift I do to the other, in a meta-political meaning. A treaty between two foreign powers and a contract, even social contract, comes after the first incontestable responsibility, my own responsibility I cannot give up to another people. Proximity does not belong to the time of clocks, too much social, too much historical, too much diplomatic; it claims for setting the record straight. Proximity disturbs this laborious synchrony who attempts to build peace. If it is an "unhistorical time" (Levinas), what could be our chances to agree on terms of a long-lasting peace?

Levinas' article, named "Peace and Proximity,” a lecture pronounced during a conference in Torino (1984) on "cultural identity of Europe," links the question of peace with his own conception of proximity. ${ }^{7}$ For Levinas, there is a contradiction in the very heart of European Consciousness: on one hand, the "centrality" of Europe, two world wars, one genocide, victim of her own "conatus;" on the other hand, peace preferred to violence. Of Levinas, we know the sentence: "Europe is Bible and Greeks.” Levinas links peace with Greek wisdom. More precisely, he sees peace from the point of view of truth, but also to the point of view of State. He tells us in a year (1984) when "centrality" of Europe has been contested from Europe itself: National independencies of hard struggle where universal values of Europe were turned back against colonial Europe, and we call today "world-wide.” Postcolonial Europe is “tired,” Levinas says. But Europe cannot give up its true centrality: the rationality of Greek philosophy. We cannot contest this centrality but with political concepts forged in Europe itself, concepts we can return against Europe itself.

Within these concepts, there is an including notion: unity of a multiplicity, like the neo-Platonic One, allusion to the Hellenistic world. Thus, a definition of True is but an idea which commands a conception of peace coming from truth. Multiplicity of nations is looking for her own ways and finding unity after the catastrophe where peace was wrecked with rationality. From this conception of unity of a multiplicity, Levinas lists knowledge which is gathering the diverse, integration of the stranger, logos preferred to war, technics, very "secularization of transcendence," able to feed human beings, and, at last, the democratic State who rules and gathers without enslaving.

There are actually two sources of peace: peace coming from truth and peace coming from State. Both bring satisfaction to understanding as well as quietness given by solidarity and reciprocity. "Peace as quietness and rest," assured on its basis. But it is also tormented from the inner by evident contradiction of wars, 
genocides, the Hitlerian madness and the reversal of emancipation into Stalinism. Truth and State may threaten Being itself, forces of Europe reversing against Europe and world. The European bad consciousness comes from it, in a time when European Union is going on, but also diversity remains. For Levinas, here is a double anguish: anguish to "commit crimes even where concepts accord themselves.” But also an anguish to the responsibility which incumbent upon each of ours in front of death or pain of the other man. Such affects overflow concepts. "This is not the intellectual deception of a system refuted by incoherency of Real which is Europe's drama," is saying Levinas. Where does this drama dwell? In what terms can we tell it? It is a matter both of "pathic" of anguish and of ethics. European crisis is not only throwing us into anguish. Such an anguish makes of crisis an "ethical moment." We ought to understand this ethic moment and assess meaning and range of it in the very heart of political thought.

For the turning point of Levinas in this article, where it seems it is only a matter of Greek inheritance of Europe, it is the biblical verse telling us Jacob's anguish. Jacob does not fear his own death, but the fear of killing his brother Esaü. Europe is Greece, but also Bible. Levinas refers implicitly peace to Hegelian trial of "identity of identity and difference," which he opposes the philosophic works of Rosenzweig, Hegel and the State, and after World War One, the premonition of another one and the redaction of the Star of Redemption. Whatever it is Hegelian history or unity of a multiplicity, truth, to which nobody in Europe thinks to escape, is deeply affected by a call coming from elsewhere, a peace ideal older than knowledge. Here Levinas incriminates deeply the satisfaction brought by concepts when they appear as unity of the diverse. But he also denounces the challenge of this plan: integrity of the Self in an organic solidarity to which the concept borrows its strength of conviction. The Self takes its place in a Whole. According to this intellectual satisfaction, there is an ideal middle class way of life: "at home," every door closed, rejecting everything coming from outdoors. This is not a pure selfishness; it is also the well-known tranquillitasanimi, a serene quietness of identic.

Levinas' plan is to ask for peace from Absolute. Absolute means: to be separate and on one's own, lonely. In any case, this Absolute is an ideal. Otherness reveals Absolute, not as a mistake of integration or a lack of community. The other man is an absolute because he does not agree with being closed into the unity of a common kind. "Peace as relation with an otherness irreducible to a common kind, where, already in a logical community, it would be but relative otherness. Peace independent of every belonging to a system, irreducible to a totality, and as if it resists to synthesis." ${ }^{8}$ Resisting to the synthesis is resisting to a synthesis of understanding, but it is also the state of mind of the one who does not get satisfied by a relative quietness which Levinas attributes to a political conception of peace. Against this political peace, Levinas opposes his own "ethical peace” which receives the other man as "absolutely Other," unassimilable and irreducible.

It seems like there are two models of peace: a political peace and an ethical peace. Do we have to oppose them: one as an alternative to the other? Do we have to think the ethical peace as overflowing the political one, or ethical peace as a stop to the political vision of peace? In another way, do we have to renounce to peace as concept and look for peace as contact? In this last case, we have to find the good formula for proximity.

Ethical peace is the only one of which we can say it is peace of love. It is the peace of unique and subjective. Love, human proximity, and peace are the same thing. Proximity within peace is not "a short distance measured in geographic space separating one another" (Levinas) like borderlines of a State. Proximity is impossible assumption of difference, impossible integration. These words, "integration," "difference," are not to understand in their meaning in a contemporary context, with polemics, political claims, and quarrels. Ethical peace authorizes the use of these words out of their context. It is important to emphasize that the "unique in its 
kind" cannot be subsumed to the unity of class or race. In a literal meaning, the same as Hegel used, the individual subsumed in the unity of a kind, becomes an insult. Here, in this uncontrolled way of thinking, lies the turn of peace with the other into hate. If the other stops to be unique, he is brought back to a class of individuals, stigmatized, relegated, and reduced into a different essence.

What Levinas is calling "love" is not love for a single person, chosen and worshiped. It is love without concupiscence, love for the neighbor: We feel unicity of the other and we refuse to see him as an element of a class. Beyond identification, Levinas uses the technical word of Husserl: “appresentation” preferred to "representation." Representation means that we keep distance with the other. As an end of this examination of ethical peace, we find again the Face, ever overflowing all his expressions, exposed to injures, to violence. This is the extreme precariousness of the other. Peace becomes "awakening to precariousness of the other." The other is no longer another, but he becomes my neighbor by assignation to me and by the request coming from him and obliging me. The neighbor is not only the fellow, the familiar one, but he becomes the end of a process of deconstruction of social roles and of the spontaneous political philosophy learned in my social life. To the peace of pure rest where I gather all attributes of my identity, Levinas substitutes peace of love for the near questioning my identity, always to fear for its unlimited freedom and power. At this stage, it seems that Levinas has substituted peace as contact to peace as concept.

In an article of the Temps Modernes review (September 1979), Politique après! ${ }^{9}$, Levinas refers the visit of Egyptian president Sadat to Jerusalem to Israel's State vocation. This vocation is no longer being victim of Universal History, but "to embody the prophetic moral and the idea of peace." It is Sadat who gives peace to Israel. It is Israel who welcomes the man of foreign, not foreign in the geographical area of the Near-East, but remote already by three wars. Sadat's visit, Levinas says, opens the only way of peace: "political weakness." This gift, strong minded said, is a weakness but to the Levinas point of view it is probably the expression of bold and strong mind. But Levinas concludes of his article named "Politiqueaprès!” is to use suggestive words, almost thought: "Peace is a concept overflowing pure political thinking." ${ }^{10}$ Peace is a concept for beyond politics, boldness of an offering gesture.

In the same way, Levinas concludes his article of 1984 (Peace and Proximity) as he did, ten years ago, in the decisive turn of Otherwise than being: the call for justice as moderation, taking into account the Third. He also repeats his question: "Who comes first? Who overtakes the other?" This question is the very sign of a peaceful mind brought to ethical bitterness of my exhibition to the other: "extreme significance in a human multiplicity of political structure of society, of laws and therefore of institutions where the 'for the other' of subjectivity enters with the dignity of citizen in perfect reciprocity of political laws, egalitarian laws or obliged to become thus." 11 We emphasize these words: "dignity of citizen.” It is one of the rare texts by Levinas in which he underlines consistency and dignity of politics. But we must add that we are not deceived: State must not carry weight for its own count. This is a wise view of civil vigilance, and it would be enough to legitimate commitment and action of many citizens. But this practical wisdom lies upon a "extravagant hypothesis," according to the words of Miguel Abensour who is reading Levinas as a "Against Hobbes." Levinas' article of 1984 ends these words: "The foundation of consciousness is justice and not the converse. Objectivity is built on justice. On extravagant nobility of 'for the other' overlaps a reasonable order, like a servant or an angel, of justice throughout knowledge, and philosophy here is a measure brought to the infinite of being-for-the-other of peace and proximity and like the wisdom of love." 12

How can we understand the meaning of "politics after!” generously inspired by Sadat’s visit. Neither taken 
in by the balance of rational State, usually credited to Europe heir of Greeks, nor hurried to undermine its foundations, Levinas crossed over the space separating us from a view got rid of politics. For other people he knew how to put limits to politics, but scarifying radical position, which is not to be thrown away and they greet it for being what it is. Some people put forward that ethical peace is a corrective to politics. Making ethics a bound to politics is, perhaps, a speculative gesture out of breath. It will be clear when we can understand what the Levinas "Against Hobbes” is.

Levinas' work is right through an explanation with the Hobbes hypothesis. Explicitly and at many moments Levinas explains Hobbes. Hobbes postulates equality between men in the state of nature. For him there are three main causes of quarrel: rivalry, suspicion, and pride. These are the three "feelings" of initial condition. They are the source of three kinds of behavior of men: profit, security, fame. These are three modes of the only "conatus.” It is not only a question of staying in being. Such ways of behavior are problematic, because they are at the roots of war of all against all. We must notice that Hobbes does not count battles as if they were aggressive brackets on a background of peace. War is a state in which you must count with the "notion of duration," just like weathermen are doing. "Indeed, as well as the nature of bad weather does not subsist in a rain shower or two, but in a tendency in this direction, during a great number of consecutive days, but in a natural ability as long as contrary is not assured."13 The tendency is that of hostility. War preparations are soon war itself. Peace appears but like a break in the clouds, on the background of a rainy weather. Every other weather is peace, Hobbes says. War is not defined as a stop of times. But peace is characterized as the temporary and changing breaking off of hostilities. The Latin version says: "time without war is peace."

As long as there is no undertaking of opposite, Hobbes, in several passages of his text, defines the place of State: Only State can suspend the state of war. State is defined as a coercive power: "a common power which keeps everybody at a respectful distance.” State's respect is not a civic duty bound to a feeling of common good, but it distances from conflicting selfish interests submitted to fear. It is a transfer of feelings, but it is overall a transfer of fear, namely of fear for violent death. At first, this fear for death is the same thing as perseverance in being and self-conservation staying in "conatus." It seems to be reason itself. Fear is necessary and sure, regarding to rational knowledge: Death is the worst evil. But why is it so necessary and sure? Not only because conatus is innocent, with a naïve expansionism, therefore the desire for conservation of his limbs and life. At once, the other is here: as my potential murderer, for Hobbes. His De Cive is opening on a desolate scene of this natural fear: "The cause of natural fear depends on, part of natural equality, part of the mutual will of injure one another.” This will is a true conatus. The mutual will is also a will to injure oneself. Death in the state of nature appears to the conatus as violent death. Neither the fear of painful and natural death, nor the pure perseverance in being are enough to go from state of nature to natural law, according to Hobbes. The affect on which lies politics is, for Hobbes, the fear of violent death and perception of the other man as my potential murderer.

After this recall of Hobbes hypothesis, we shall examine the "Against Hobbes" of Levinas. Levinas, far from every kind of enquiry or anthropology, in difference with the ethnologist Pierre Clastres, himself opposite to Hobbes, starts of a hypothesis absolutely irrelevant to Hobbes. Generosity cannot come from nothing, ex nihilo. Generosity is inscribed in human tie. It could not substitute to selfishness of striking instincts, if unselfishness was not an essential category of human. Levinas, intensifying the trial he makes to ontology, relates the self-interest (interesse) to Being. Self-interest, in the meaning of sharing profits, is not purely a calculation. Self-interest is first of all the expression of conatus, even before a value judgment as selfishness. The intrigue of interests carries on conatus question in the very heart of war and peace problematics. 
It is not so easy to think peace with ontological terms. Peace is for Levinas, the reign of reason. In the first instance, reason suspends the clash of human beings. It brings the offer of a mediation: It needs a mediating State. But this peace is also an exercise of patience. It is time's work; it implies more than a mere arbitration. Peace is negotiation, dialog, and "trade." Here is the initial position. Its most brutal formulation is: "politics after!” For initiative of Sadat's visit in Jerusalem refers to the eschatology of peace as Levinas sees it. If we want a long lasting peace, we need to bet on future. It is time for compensation more than to reparation. "Nothing is disinterested," Levinas says. "The mass is permanent and self-interest remains. Transcendence is artificial and peace unstable." ${ }^{, 4}$ Peace remains closed on present: gathering of people who were fighting each other yesterday. Every peace is for now, with a dimension of memory and history. But memory and history are powerless to break the synchrony of present. Future is thrown out by the imminence of a resumption of war or by the diplomatic shivery. The present itself is cluttered up with historiographic representations. Peace, for Levinas, does not stand up against self-interests.

And yet trade is already better than war. If peace is only a break in the clouds, as Hobbes says, it contains however a promise. "Good already ruled in peace," writes Levinas. Peace is an opening to the time for promise; it is eschatological. In peace, the mind holds on its breath, as if he was surprised of the possibility to suspend self-interest. As if we would be able to go from essence in war to existence in peace. The originality of Levinas' thought must also be discovered in his Talmudic Lectures where he questions Talmudic tradition about the victory of Rome. Will Rome triumph over its enemies because it is the strongest power? Because, according to the Hegelian scheme, its time has come to make the first move on the stage of History? Maybe Rome's victory is playing on another stage? What is Rome for the wise men who wrote the Talmud? Levinas resumes for his own philosophy their discussions:

Wicked State, but perfectly State. Exceptional and successful outcome of violence able to balance. State which would have not reached ethical law, following from life of one man for the other; but law which would make its own way through animality, to reach in a dialectical way formal universality of law, even when brother will turn on brother (homo homini lupus). Appearance of moral law, but formally law; in this appearance; in this formalism. ${ }^{15}(1982,84)$

Levinas accepts from Rome its Right and its notion of Persona. But Rome remains still a State as the others. Born in violence, it is lasting in violence and will probably sink in violence, Rome has not gone from Hobbes to Levinas. Yet for Levinas, Rome has gone through the "animality" of its war expansionism to deliver a thought about mankind. By its balance in violence, Roman State is authoritative. Not as a model. However, we can adopt its institutions. Roman formalism is the best of Rome. Levinas writes: "Roman legalism is the positive effect of its negativity." 16 Though it was an animal, Rome is able to stop "animal human hordes.” A Talmudic treatise, Pirke Avot (lessons of the fathers of world), enounces: "Pray for the State, otherwise men will swallow each other.”

Is this a return to Hobbes? The contradiction is only outward. No fascination for the State, for it has no last word. The title of this Talmudic Lecture by Levinas is precisely: "Who is the last to play?” According to Talmudic tradition, Rome will rule over the world during nine months, which is the messianic gestation. Rome is a pre-messianic State, a necessary stage for the building of human. Because it gives a universal legal frame to ethical life, "Rome requires law and procedure of every creature" (Levinas). Born in violence, Roman state prepares the coming of an order he cannot guess, higher than him, but to which he remains essential. Levinas tries to think beyond the State, to see, through the State, a human emancipation, expressed in messianic categories. 
Peace, awakening to proximity to the other man, is issued of my responsibility for him. This responsibility, for Levinas, leads to the possibility of dying for the other. But it cannot be a feeling of suffocation for the other man. This proximity obliges nobody but me. If there is something extravagant in this welcome, it is yet limited, i.e., understood and evaluated in politics. Levinas does not scorn politics, but politics is not for him an impassable horizon. The welcome of foreigners, when they are prosecuted, stateless, or refugees, lies on justice. In the treatise of wisdom, Pirke Avot, we can read that the world lies on three pillars: truth, justice, and peace. Without justice, you will never find peace. Feeling of injustice is feeding war. But proximity, as a superlative approach of the neighbor, opens perspectives to peace. Giving peace first to the far is a way to avoid a war. But it is also welcome the far: proximity is the reduction of strangeness of far, without assimilation, without fusion.

\title{
Notes
}

\author{
1. Léon Blum, A l'échelle humaine, Gallimard, Paris, 1945. \\ 2. Maurice Blanchot, La condition critique, Articles 1945-1998, Paris, Gallimard. \\ 3. Emmanuel Levinas, En découvrant l' existence avec, Husserl et Heidegger, Paris, VRIN, 1982, 217-36. \\ 4. Emmanuel Levinas, 229. \\ 5. Ibid., 229. \\ 6. Emmanuel Levinas, Autrement qu'être, ou au-delà de l'essence, Martinus Nijhoff, La Haye, 1974, 104. \\ 7. Les cahiers de la nuit surveillée, Emmanuel Levinas, Verdier, Lagrasse, 1984, 339-46. \\ 8. Emmanuel Levinas, Paix et proximité, 341. \\ 9. Emmanuel Levinas, Au-delà du verset, Paris, Editions de Minuit, 1982, 222-8. \\ 10. Emmanuel Levinas, ibid., 228. \\ 11. Paix et proximité, 345. \\ 12. Ibid., 346. \\ 13. Thomas Hobbes, Leviathan, from a French translation, François Tricaud, SIREY, Paris, 1983. \\ 14. Emmanuel Levinas, Totalité et Infini, Martinus Nijhoff, La Haye, 1965, 5. \\ 15. Emmanuel Levinas, L'au-delà du verset, Paris, MINUIT, 1982, 84. \\ 16. Emmanuel Levinas, L'au-delà du verset, 85.
}

